\title{
ETHzürich
}

ETH Library

\section{Effects of landscape elements on the distribution of the rare bumblebee species Bombus muscorum in an agricultural landscape}

\author{
Journal Article \\ Author(s): \\ Diekötter, Tim; Walther-Hellwig, Kerstin; Conradi, Manuel; Suter, Matthias; Frankl, Robert \\ Publication date: \\ 2006-01 \\ Permanent link: \\ https://doi.org/10.3929/ethz-b-000022878 \\ Rights / license: \\ In Copyright - Non-Commercial Use Permitted \\ Originally published in: \\ Biodiversity and Conservation 15(1), https://doi.org/10.1007/s10531-004-2932-9
}




\title{
Effects of landscape elements on the distribution of the rare bumblebee species Bombus muscorum in an agricultural landscape
}

\author{
TIM DIEKÖTTER ${ }^{1, *}$, KERSTIN WALTHER-HELLWIG ${ }^{2}$, MANUEL \\ CONRADI $^{3}$, MATTHIAS SUTER $^{3}$ and ROBERT FRANKL ${ }^{3}$ \\ ${ }^{1}$ Geobotanical Institute ETH Zurich, Zürichbergstrasse, 38, 8044 Zürich, Switzerland; ${ }^{2}$ Department \\ of General and Special Zoology - Animal Ecology, University Giessen, Germany; ${ }^{3}$ Department of \\ Biology, Nature Conservation, University Marburg, Germany; *Author for correspondence (e-mail: \\ tim.diekoetter@env.ethz.ch; phone: +41-1-632-4588; fax: +41-1-632-1215)
}

Received 24 December 2003; accepted in revised form 10 August 2004

Key words: Distribution, Endangered pollinators, Floral resources, Foraging behaviour, Habitat fragmentation, Spatial structure, Landscape analysis

\begin{abstract}
The regional distribution pattern of Bombus muscorum was studied in an agricultural landscape of central Germany, one of two remaining areas with the occurrence of this nationally endangered species in the Land Hesse. To determine the landscape characteristics that facilitate the occurrence of B. muscorum, grid-based observation records were analysed in a GIS environment at a regional scale. A significantly negative effect of the number of trees on the occurrence of B. muscorum and a significantly positive one of the proportion of arable land, strongly support the species' preference for open landscapes. Yet, apart from open landscapes additional landscape features were shown to be important. A significantly positive effect of ditches in the final model revealed the importance of this landscape element for the occurrence of B. muscorum. This finding was additionally supported by recordings of nest-searching queens, nests, and flower visits along dithes. The positive effects of clover and fallow land indicate the species' need for suitable food resources throughout the season. Because B. muscorum exhibits small foraging ranges, it is essential that landscape elements that provide nesting sites, foraging habitats and undisturbed hibernation structures are next to each other. The low numbers of individuals of B. muscorum recorded indicate that the supply of these habitat elements may have reached a critical threshold in the study region.
\end{abstract}

\section{Introduction}

Since the intensification of agriculture during the 1950s the hitherto positive correlation between agricultural practices and species diversity became negative (Stoate et al. 2001). Declines in number of species in agricultural landscapes have been shown for plants and numerous animal groups (Sotherton and Self 1999). Pollinators, one of the most important functional groups in the landscape, are also negatively affected by modern agricultural techniques and the concurrent landscape changes (Williams 1989; Osborne and Corbet 1994; Buchmann and Nabhan 1996). In this regard, bumblebees are no exception; several species in Europe show diminishing ranges and declines in numbers (Williams 1986; Rasmont 1988; Williams et al. 1991). 
The conversion from hay to silage production as well as the intensification of grassland management (Stoate 1996) has reduced suitable habitats for bumblebees. Furthermore, continuing enlargement of arable fields results in increasing fragmentation of remaining biotopes, such as hedgerows, field boundaries, ditches or path margins. The composition of the landscape is being severely altered (Meeus 1993), yet, the close proximity of certain habitats is often essential for the survival of species in a given landscape. Especially in the case of bumblebees, as central-place foragers, the spatial neighbourhood of nesting sites and foraging habitats, as well as the existence of undisturbed places for hibernation is essential (Svensson et al. 2000; Carvell 2002).

The maintenance of a diverse set of species within the taxon of bumblebees (Bombus) is of great value, not only from a conservational point of view, but also from an economical one. Besides many wild flowers, bumblebees pollinate numerous cultivated crops (Free 1993; O’Toole 1993; Watanabe 1994). Flowers with long corollas are especially dependent on the long-tongued species of bumblebees, such as B. muscorum (Rasmont et al. 1993). Whereas numerous studies have addressed foraging behaviour and distribution patterns of bumblebees at a small scale, such as within and between patches of flowers (Thomson 1996; Goverde et al. 2002), only recently has movement of bumblebees been studied at a landscape scale (Osborne et al. 1999; Walther-Hellwig and Frankl 2000; Bhattacharya et al. 2003; Kreyer et al. 2004). Analysing the effect of landscape structure on species richness and abundance of all species of bumblebees together, Steffan-Dewenter et al. (2002) did not find any significant result at neither spatial scale considered. However, it is highly probable that bumblebee species display species-specific activity ranges (Walther-Hellwig and Frankl 2000) and therefore react to the landscape structure at species-specific spatial scales.

B. muscorum, a species showing small activity ranges (Walther-Hellwig and Frankl 2000), occurs throughout Europe but disappeared from most of its range in the UK (Goulson 2003 and references therein) and is listed as endangered on the red list in Germany (Westrich et al. 1998).

The aim of the present study was to define the landscape characteristics that facilitate the occurrence of the critically endangered species B. muscorum in the 'Amöneburger Becken'. A geographic information system (GIS) was used to analyse this intensively used agricultural landscape, accommodating one of the remaining two verified populations of $B$. muscorum in the Land Hesse, Germany (Frommer 2001; Tischendorf 2001).

\section{Methods}

Study area and sampling

The study was conducted in the 'Amöneburger Becken', a basin landscape near Marburg, Hesse (Germany). Bumblebees were surveyed in an area of $60 \mathrm{~km}^{2}$ 
(Gauss-Krueger coordinates of the centre point: 3492000 , 5627500), ranging from 200 to $305 \mathrm{~m}$ above sea level. Ditches and brooks drain this formerly wet basin landscape, allowing for intensive agriculture on the predominant loess soils in the area. Except for small villages often surrounded by orchards, the landscape is open showing only few vertical landscape elements (Figure 1).

To create distribution maps of B. muscorum Reinig, a $1 \mathrm{~km}^{2}$ grid was projected on the study area. Quadrats to be investigated were chosen systematically. In total, 31 out of 60 quadrats were sampled (Figure 2). Each of the sample quadrats chosen was investigated on five dates.

On each observation date, $70 \mathrm{~min}$ were spent in a quadrat to search for B. muscorum: spots of aggregated food resources were investigated for $30 \mathrm{~min}$ altogether, preferably six different locations were sampled for 5 min each; the remaining $40 \mathrm{~min}$ were available for the location of aggregated food resources along linear landscape elements (e.g. road and field margins, hedges, ditches and forest edges). Species name, sex, caste, and visited food resource as well as the quadrant $(0.5 \mathrm{~km} \times 0.5 \mathrm{~km})$ in which a bumblebee was encountered were recorded during stationary observations and transect walks. Abundances were noted during transect walks only, to avoid double counts. Walking distances during the search for food resources were kept to around $3 \mathrm{~km}$ per quadrat and investigation. Landscape elements checked for bumblebees differed in width but showed a total width of around $2 \mathrm{~m}$ most of the time. All accessible linear

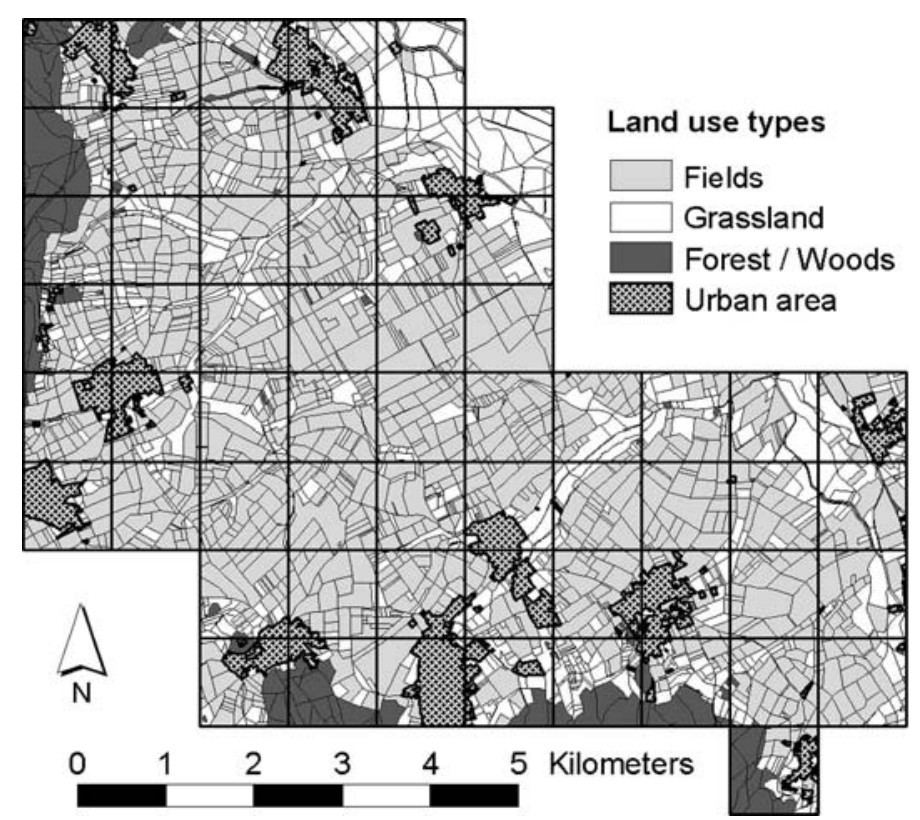

Figure 1. General map of the study area 'Amöneburger Becken' and distribution of main land use types. 


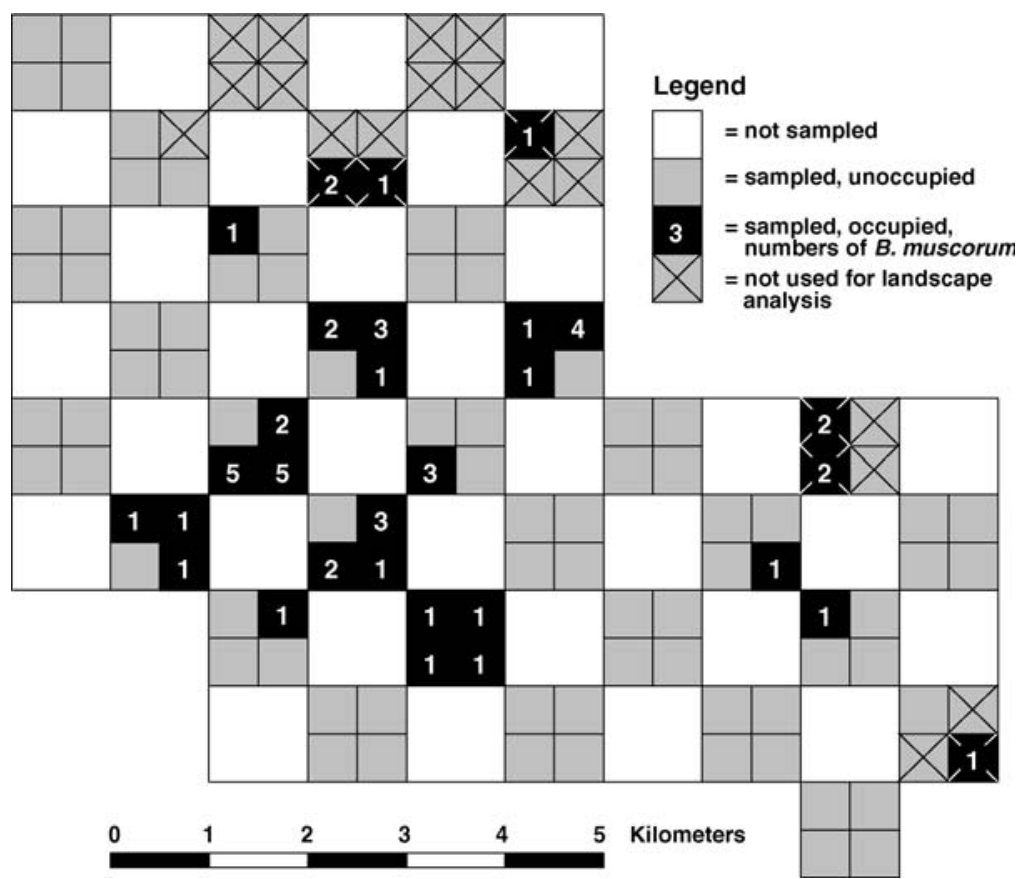

Figure 2. Distribution patterns of Bombus muscorum within the 'Amöneburger Becken'. Sampling units are underlayed in grey; presence of Bombus muscorum is indicated by black colour. Digits show abundances. Due to missing information for the landscape model, crossed sampling units were not used for spatial analyses.

landscape elements were covered over the whole sampling period. All individuals assigned to the species B. muscorum were caught with an insect net and checked for the absence of black hairs on the thorax to prevent mistake with B. humilis.

The order of quadrats to be investigated was changed randomly. Sampling took place from the beginning of June to the end of August 2001, between 0800 and $2000 \mathrm{~h}$ at temperatures above $12{ }^{\circ} \mathrm{C}$ on days without rain and stormy wind.

\section{Landscape-models and analysis}

Intensive mapping of land use and landscape elements within the study area during the years 1999 and 2000 (Walther-Hellwig 2001), as well as aerial photographs from 1999, provided the landscape information used in the present vector based GIS-landscape-models. The vertical structure, the potential supply of pollen and nectar and the suitability for nesting and hibernation of landscape elements guided the model-building. Models encompassed 
field crops with a detailed mapping of potential food resources including orchards, semi-natural landscape elements, single trees as well as woodlands and urban structures (Table 1). The topology of woodlands and urban areas as well as of semi-natural landscape elements, such as hedgerows, banks, ditches etc. showed only marginal changes over the mapping period. Superabundant food resources such as rape, clover, beans etc. were updated by additional mapping during fieldwork.

All spatial analyses were performed in ArcView 3.2 (ESRI Geoinformatik, Hannover, Germany) enhanced by several scripts and extensions, using the $0.5 \mathrm{~km} \times 0.5 \mathrm{~km}$ grid. Due to missing landscape information on the margins of the study area, only a subset of 100 sampling units (Figure 2) could be considered while analysing the occurrence of B. muscorum in relation to landscape

Table 1. Landscape elements mapped as polygons, lines or points.

\begin{tabular}{|c|c|c|}
\hline & LE & $\mathrm{V}$ \\
\hline Polygon-Layer & {$[\%]$} & \\
\hline Camelina sativa (L.) Crantz & $<0.1$ & 1 \\
\hline Helianthus annuиs L. & $<0.1$ & 1 \\
\hline Phacelia tanacetifolia Bentham & $<0.1$ & 1 \\
\hline Sinapis arvensis $\mathrm{L}$. & 0.1 & 1 \\
\hline Solanum tuberosum L. & 0.4 & 1 \\
\hline Legumes & 0.1 & 1 \\
\hline Pisum sativum ssp. L. & 1.0 & \\
\hline Vicia faba $\mathrm{L}$. & 1.0 & \\
\hline Brassica napus L. & 6.0 & \\
\hline Trifolium pratense $\mathrm{L}$. & 0.9 & 2 \\
\hline Trifolium repens $\mathrm{L}$. & 0.2 & 2 \\
\hline Fallow land & 1.1 & \\
\hline Arable land & 51.7 & \\
\hline Grassland & 22.3 & \\
\hline Hedgerows and groves & 0.5 & 3 \\
\hline Woodland & 6.6 & 3 \\
\hline Orchards & 0.5 & 4 \\
\hline Rural settlements & 8.0 & 4 \\
\hline Line-Layer & {$[\mathrm{km}]$} & \\
\hline Brooks & 47.9 & \\
\hline Ditches & 18.3 & \\
\hline Flower-rich banks & 14.8 & 5 \\
\hline Flower-rich structures & 3.1 & 5 \\
\hline Grassland elements & 6.8 & \\
\hline Flower-rich hedgerows & 1.5 & 6 \\
\hline Hedgerows & 10.3 & 6 \\
\hline Rows of trees & 4.4 & 6 \\
\hline Field paths & 355.9 & \\
\hline Streets & 82.2 & \\
\hline Point-Layer & {$[n]$} & \\
\hline Trees & 2416 & \\
\hline
\end{tabular}

$\mathrm{LE}=$ quantities of mapped landscape elements in the Amöneburger Becken; V: '\#' variables assigned to new groups. 
structure. The reduced area comprised only 24 of the 30 sampling units found to be occupied by B. muscorum. A multiple logistic regression was performed on the occurrence of $B$. muscorum in quadrants $(0.5 \mathrm{~km} \times 0.5 \mathrm{~km})$ against the numbers of bumblebees encountered besides $B$. muscorum and the landscape variables mapped. Several landscape variables were combined in ecologically meaningful groups prior to analysis to prevent problems in convergence. The following groups were established: flower resources of rare crops (1), clover (2), woody structures (3), adjacent vertical structures (4), linear flower resources (5), and linear vertical structures (6) (Table 1). The new variable (3) was log-transformed to prevent the Hauck-Donner effect (Hauck and Donner 1977). Stepwise backward selection using the stepAIC procedure was applied for model reduction. All statistical analyses were performed using the statistical software R, version 1.7.1. (The Free Software Foundation Inc., Boston, USA).

\section{Results}

Presence, absence, abundance and food resources

During the present study 7 queens, 44 workers and 2 males of B. muscorum were recorded, representing $1.7 \%$ of the total number of bumblebees observed. B. muscorum was present in 30 of 124 quadrants $(0.5 \mathrm{~km} \times 0.5 \mathrm{~km})$ (Figure 2). Individuals of $B$. muscorum were found visiting 13 different plant species; eight individuals were observed in flight. Trifolium pratense was most frequently used. Four out of 21 flower visits to $T$. pratense were recorded on agricultural cultivations (Table 2).

Table 2. Plant species utilized by Bombus muscorum and number of individuals observed on each plant species.

\begin{tabular}{ll}
\hline Species & $\begin{array}{l}\text { Number of observed individuals } \\
\text { of Bombus muscorum }\end{array}$ \\
\hline Trifolium pratense L. & 21 \\
Trifolium repens L. & 8 \\
Vicia cracca L. & 3 \\
Lotus corniculatus L. & 2 \\
Lotus pedunculatus Cav. & 2 \\
Phacelia tanacetifolia Benth. & 2 \\
Stachys palustris L. & 1 \\
Centaurea jacea L. & 1 \\
Vicia sepium L. & 1 \\
Cirsium vulgare (Savi) Ten. & 1 \\
Lythrum salicaria L. & 1 \\
Galeopsis pubescens Bess. & 1 \\
Lathyrus pratensis L. & 1 \\
\hline
\end{tabular}


Table 3. Results of the multiple logistic regression (based on the presence of Bombus muscorum, numbers of individuals of other bumblebee species, and landscape composition).

\begin{tabular}{lllll}
\hline Variable & Estimate & $\mathrm{SE}$ & $z$-value & $p$ \\
\hline Intercept & $-4.194 \mathrm{e}+00$ & $1.480 \mathrm{e}+00$ & -2.834 & 0.005 \\
Clover $(2)^{\mathrm{a}}$ & $8.674 \mathrm{e}-05$ & $5.813 \mathrm{e}-05$ & 1.492 & 0.136 \\
Arable land & $1.727 \mathrm{e}-05$ & $6.857 \mathrm{e}-06$ & 2.519 & 0.012 \\
Fallow land & $9.305 \mathrm{e}-05$ & $5.800 \mathrm{e}-05$ & 1.604 & 0.109 \\
Trees & $-1.002 \mathrm{e}-01$ & $4.326 \mathrm{e}-02$ & -2.318 & 0.020 \\
Ditches & $3.381 \mathrm{e}-03$ & $1.589 \mathrm{e}-03$ & 2.128 & 0.033 \\
\hline
\end{tabular}

Originally, all 20 variables were fitted; the model was reduced using a stepwise backward selection with the AIC as criterion to omit terms.

${ }^{\text {a }}$ Clover is a combined variable, see Table 1.

\section{Landscape analysis and evaluation of landscape elements}

The predominant landuse in the 'Amöneburger Becken' is arable agriculture including several crops $(60.7 \%$ of study area). Furthermore, intensively used meadows can be found on $22.3 \%$ of the area, in large parts along the river $\mathrm{Ohm}$. Rural settlement structures make up an area percentage of $8 \%$. Villages are often surrounded by orchards $(0.5 \%)$. Forests, mainly found at the southern and western margins of the basin cover $6.6 \%$ of the study area. Table 1 contains area percentages (plane), lengths (linear) and numbers (punctual) of all landscape elements investigated.

The stepwise backward selection for the logistic regression retained five of 20 variables that were included in the original model (Table 3). The final model contained the variables arable land and ditches that showed significantly positive effects on the occurrence of B. muscorum. Also the presence of clover and fallow land contributed to the occurrence of the species in a positive way. In contrast, the number of trees showed a significantly negative effect on the presence of B. muscorum (Table 3).

\section{Discussion}

Most B. muscorum were found in the central parts of the study area, matching exactly those areas most intensively used for agricultural purposes. However, this surprising observation mirrors the distinctive habitat requirements of B. muscorum.

The significantly negative effect of the number of trees on the occurrence of B. muscorum reflects the species' preference for open landscapes (Dylewska 1957; Reinig 1970). This is supported by the observation that out of 24 analysed sampling units occupied by B. muscorum two only included rural settlements and none woodland. Accordingly we assume that the significantly positive effect of the landscape variable arable land on the occurrence of B. muscorum is not caused by the type of crop cultivated, but the absence of 
vertical landscape elements on the area under crop within the inner part of the study area.

The avoidance of vertical landscape structures at a regional scale mirrors the species' main distribution along coastal areas at the biogeographical scale (Reinig 1970; Wagner 1971; Peters 1972; Westrich 1990; Pekkarinen and Teras 1993; Plowright et al. 1997). Under natural conditions, B. muscorum probably mainly occurs in the open landscapes of coastal areas. It seems that the increase of open landscapes in the interior, due to human activities, caused an expansion of the distribution ranges of B. muscorum. Accordingly, $B$. muscorum has been recorded in open regions of the interior by several authors (Dylewska 1957; Reinig 1970; Westrich 1990).

However, despite the omnipresence of open landscapes, such as intensively used agricultural landscapes (Statistisches Bundesamt 2002), B. muscorum is regarded as an endangered species in Germany (Jedicke 1997; Westrich et al. 1998) and appears to be very rare in the interior (Wolf 1985; Hagen 1994).

Nowadays, wet lowlands seem to be the only remaining habitat in the interior suitable for B. muscorum (Westrich 1990; Treiber 1998). The significantly positive effect of ditches on the occurrence of B. muscorum, together with the frequently observed nest-searching behaviour of queens and the two findings of nest along brooks and ditches, leads us to the assumption that these landscape elements are essential to meet the habitat requirements of this bumblebee species (see also Reinig 1970). Comparably high shares of brooks and ditches occur within the central part of the formerly wet floodplain 'Amöneburger Becken' (Rittweger 1997), and are therefore regarded to be the main reason for this landscape harbouring one of the two remaining populations of B. muscorum in the Land Hesse (Frommer 2001; Tischendorf 2001).

In addition to their location on the north-facing slope of a small brook the observed nests of $B$. muscorum were close to fields of $T$. pratense. With regard to this observation, the positive effects of clover and fallow land, and the recordings of flower visits, an additional requirement essential for the presence of B. muscorum became apparent - the provision of suitable food resources in spatial proximity to nesting-sites. Long-tongued bumblebee species, such as $B$. muscorum, show comparably low competition abilities on super-abundant flower resources like rape (Heinrich 1974; Ranta and Vepsalainen 1981; Plowright et al. 1997). Furthermore, in most years there is only a small overlap of this particular resource with the seasonal occurrence of B. muscorum, as this species is emerging relatively late. In accordance, recorded flower visits showed that agricultural cultivations of plants with long corollas such as $T$. pratense and $T$. repens are frequently utilized by this bee. $T$. pratense is grown extensively throughout the 'Amöneburger Becken' and is harvested on demand during a great part of the growing season. Contrary to modern silage production, this technique results in a higher percentage and a greater continuity of flowering plants. However, the periodicity of agricultural resources makes alternative foraging habitats, such as fallow land, essential (Backman and Tiainen 2002; Croxton et al. 2002). 
Flower visits to the important forage species $T$. pratense and T. repens were also frequently recorded on plants growing on taluses, path- and field-margins. Vicia cracca, V. sepium and Lotus corniculatus occur in these linear grassland elements, too. Furthermore, B. muscorum was recorded on L. pedunculatus, Lythrum salicaria, Galeopsis pubescens and Stachys palustris all growing along brooks and ditches. This shows that besides the required nesting-sites brooks and ditches also supply valuable food resources. With the exception of Phacelia tanacetifolia, all floral resources visited by this bumblebee species underline the importance of non-cultivated flower-rich elements (Kells and Goulson 2003) or semi-natural grasslands (Söderström et al. 2001) within the open landscape.

Continuous enlargement of agricultural fields and the disappearance of extensively used grasslands or non-crop features such as field margins and ditches (Stoate et al. 2001) result in an impoverished landscape not only in terms of nectar and pollen resources but also in terms of suitable sites for nesting and hibernation (Riemann 1987; Jennersten et al. 1993). Increasing levels of competition for the remaining resources between different species of bumblebees or within the guild of pollinators might be a consequence. This seems not yet to be the case in the study area as the present analysis did not reveal any effect of numbers of individuals of other bumblebee species recorded in the area on the occurrence of B. muscorum.

Actual sizes of agricultural fields below the regional average (Hessisches Statistisches Landesamt 1999) might indicate a higher proportion of edge structures within the 'Amöneburger Becken' compared to other intensively used agricultural areas in the Land Hesse. This circumstance, besides the numerous brooks and ditches draining this basin landscape, seems to be another landscape characteristic that allows B. muscorum, a species supposed to have comparatively small foraging ranges (Walther-Hellwig and Frankl 2000) and presumably low competitive abilities on mass-flowering crops, to still exist in this area.

Although Williams $(1986,1989)$ argues that the patterns of abundance of bumble species in the UK are best explained by their climatic optima and declining populations as observed in B. muscorum might also be affected by climatic shifts (cf. Thomas et al. 2004), we regard the continuing impoverishment of the landscape in terms of semi-natural landscape elements as one of the main factors that negatively affects population sizes and distributions ranges of B. muscorum. The survival of B. muscorum within the 'Amöneburger Becken' will be crucially dependent on the establishment and the spatial connectivity of landscape elements providing habitats for nesting, foraging and hibernating such as ditches and flower-rich fields, margins or banks.

\section{Acknowledgements}

This study was supported by grants of the Philipps University Marburg. We would like to thank numerous farmers for their kind cooperation in the field. 
T.D. is also grateful for the support by the Geobotanical Institute ETH Zurich and valuable advices by $\mathrm{S}$. Güsewell and R. Billeter. We also would like to thank two anonymous reviewers for valuable comments on an earlier version of this manuscript.

\section{References}

Backman J.P.C. and Tiainen J. 2002. Habitat quality of field margins in a Finnish farmland area for bumblebees (Hymenoptera: Bombus and Psithyrus). Agric. Ecosyst. Environ. 89: 53-68.

Bhattacharya M., Primack R.B. and Gerwein J. 2003. Are roads and railroads barriers to bumblebee movement in a temperate suburban conservation area? Biol. Conserv. 109: 37-45.

Buchmann S.L. and Nabhan G.P. 1996. The Forgotten Pollinators. Island Press/Shearwater Books, Washington, DC, USA.

Carvell C. 2002. Habitat use and conservation of bumblebees (Bombus spp.) under different grassland management regimes. Biol. Conserv. 103: 33-49.

Croxton P.J., Carvell C., Mountford J.O. and Sparks T.H. 2002. A comparison of green lanes and field margins as bumblebee habitat in an arable landscape. Biol. Conserv. 107: 365-374.

Dylewska M. 1957. The distribution of the species of the genus Bombus Latr. in Poland. Acta Zool. Cracov. 2: 259-278.

Free J.B. 1993. Insect Pollination of Crops. Academic Press, London, UK.

Frommer U. 2001. Bestandsaufnahme der Bienenfauna im Mittleren Hessen (Hymenoptera, Apidae). Naturwissenschaftliche Veröffentlichungen Darmstadt/Bericht N.F. 24: 129-191.

Goulson D. 2003. Bumblebees. Their Behaviour and Ecology. Oxford University Press, Oxford, UK.

Goverde M., Schweizer K., Baur B. and Erhardt A. 2002. Small-scale habitat fragmentation effects on pollinator behaviour: experimental evidence from the bumblebee Bombus veteranus on calcareous grasslands. Biol. Conserv. 104: 293-299.

Hagen E. von 1994. Hummeln: Bestimmen, Ansiedeln, Vermehren, Schützen. Naturbuch Verlag, Augsburg, Germany.

Hauck W.W. and Donner A. 1977. Wald's test as applied to hypotheses in logit analysis. J. Am. Stat. Assoc. 72: 851-853.

Heinrich B. 1979. Bumblebee Economics. Harvard University Press, Cambridge, MA and London. Hessisches Statistisches Landesamt 2000. Statistisches Handbuch Hessen 1999/2000. Landesamt, Wiesbaden, Germany.

Jedicke E. (ed.), 1997. Die Roten Listen: Gefährdete Pflanzen, Tiere, Pflanzengesellschaften und Biotope in Bund und Ländern. Ulmer, Stuttgart, Germany.

Jennersten O., Loman J., Møller A.P., Robertson J. and Widén B. 1993. Conservation biology in agricultural habitat islands. In: Hansson L. (ed.), Ecological Principles of Nature Conservation: Applications in Temperate and Boreal Environments. Elsevier Applied Science, London, UK.

Kells A.R. and Goulson D. 2003. Preferred nesting sites of bumblebee queens (Hymenoptera : Apidae) in agroecosystems in the UK. Biol. Conserv. 109: 165-174.

Kreyer D., Oed A., Walther-Hellwig K. and Frankl R. 2004. Are forests potential landscape barriers for foraging bumblebees? Landscape scale experiments with Bombus terrestris agg. and Bombus pascuorum (Hymenoptera, Apidae). Biol. Conserv. 116/1: 111-118.

Meeus J.H.A. 1993. The transformation of agricultural landscapes in Western Europe. Sci. Total Environ. 129: 171-190.

Osborne J.L., Clark S.J., Morris R.J., Williams I.H., Riley J.R., Smith A.D., Reynolds D.R. and Edwards A.S. 1999. A landscape-scale study of bumblebee foraging range and constancy, using harmonic radar. J. Appl. Ecol. 36: 519-533.

Osborne J.L. and Corbet S.A. 1994. Managing habitats for pollinators in farmland. Aspects Appl. Biol. 40: 207-215 
O’Toole C. (ed.), 1993. Diversity of Native Bees and Agroecosystems. CAB International, Wallingford, UK.

Pekkarinen A. and Teras I. 1993. Zoogeography of Bombus and Psithyrus in Northwestern Europe (Hymenoptera, Apidae). Ann. Zool. Fennici 30: 187-208.

Peters G. 1972. Ursachen für den Rückgang der seltenen heimischen Hummelarten (Hym., Bombus et Psithyrus). Entomol. Berichte 85-90.

Plowright C.M.S., Plowright R.C. and Williams P.H. 1997. Replacement of Bombus muscorum by Bombus pascuorum in northern Britain. Can. Entomol. 129: 985-990.

Ranta E. and Vepsalainen K. 1981. Why are there so many species - spatio-temporal heterogeneity and Northern bumblebee communities. Oikos 36: 28-34.

Rasmont P. 1988. Monographie écologique et zoogéographique des bourdons de France et de Belgique (Hymenoptera, Apidae, Bombinae). Faculté des Science Agronomique de l'Ètat, Gembloux, Belgium.

Rasmont P., Leclercq J., Jacob-Remacle A., Pauly A. and Gaspar C. 1993. The faunistic drift of Apoidea in Belgium. In: Bruneau E. (ed.), Bees for Pollination. Commission of the European Communities, Brussels, pp. 65-87.

Reinig W.F. 1970. Ökologische Studien an mittel- und südosteuropäischen Hummeln (Bombus Latr., 1802) (Hym., Apidae). Mitteilungen der Münchner Entomologischen Gesellschaft 60: $1-56$.

Riemann H. 1987. Bienen, Wespen und Ameisen (Hymenoptera Aculeata) als Besiedler von Böschungen an tiefliegenden Entwässerungsgräben. Abh. Naturwiss. Ver. Bremen 40: 333-346.

Rittweger H. 1997. Spätquartäre Sedimente im Amöneburger Becken - Archive der Umweltgeschichte einer mittelhessischen Altsiedellandschaft. In: Hermann F.-R. (ed.), Materialien zur Vor- und Frühgeschichte von Hessen. Selbstverlag des Landesamt für Denkmalpflege, Wiesbaden, Germany.

Söderström B., Svensson B., Vessby K. and Glimskär A. 2001. Plants, insects and birds in semi-natural pastures in relation to local habitat and landscape factors. Biodiv. Conserv. 10: 1839-1863.

Sotherton N.W. and Self M.J. 1999. Changes in plant and arthropod biodiversity on lowland farmland: an overview. In: Aebischer N.J., Evans A.D., Grice P.V. and Vickery J.A. (eds), Ecology and Conservation of Lowland Farmbirds. British Ornithologists' Union, Tring, pp. 26-35.

Statistisches Bundesamt (ed.), 2002. Statistisches Jahrbuch 2002 für die Bundesrepublik Deutschland. Neuster Verlag, Stuttgart, Germany.

Steffan-Dewenter I., Munzenberg U., Burger C., Thies C. and Tscharntke T. 2002. Scale-dependent effects of landscape context on three pollinator guilds. Ecology 83: 1421-1432.

Stoate C. 1996. The changing face of lowland farming and wildlife, Part 2 1945. Brit. Wildlife 7: $162-172$.

Stoate C., Boatman N.D., Borralho R.J., Carvalho C.R., de Snoo G.R. and Eden P. 2001. Ecological impacts of arable intensification in Europe. J. Environ. Manage. 63: 337-365.

Svensson B., Lagerlöf J. and Svensson B.G. 2000. Habitat preferences of nest-seeking bumble bees (Hymenoptera: Apidae) in an agricultural landscape. Agric. Ecosyst. Environ. 77: 247-255.

Thomas C.D., Cameron A., Green R.E., Bakkenes M., Beaumont L.J., Collingham Y.C., Erasmus B.F.N., de Siqueira M.F., Grainger A., Hannah L., Hughes L., Huntley B., van Jaarsveld A.S., Midgley G.F., Miles L., Ortega-Huerta, M.A., Peterson A.T., Phillips O.L. and Williams S.E. 2004. Extinction risk from climate change. Nature 427: 145-148.

Thomson J.D. 1996. Trapline foraging by bumblebees. 1. Persistence of flight-path geometry. Behav. Ecol. 7: 158-164.

Tischendorf S. 2001. Wildbienen und Wespen (Hymenoptera: Apidae) im Oberrheinischen Auwaldgebiet "Kühkopf-Knoblauchsaue" (Hessen). Hessische Faunistische Briefe 20: 21-42.

Treiber R. 1998. Verbreitung und Ökologie der Hummeln (Hymenoptera: Apidae) im Landkreis Freudenstadt (Baden-Württemberg). Mit. bad. Landesver. Naturkunde und Naturschute, N.F. 17: $155-180$. 
Wagner R. 1971. Die Veränderung der Hummelfauna Cuxhavens in diesem Jahrhundert. Der Versuch einer Deutung. Entomologische Mitteilungen des Zoologischen Museums Hamburg 4: 207-232.

Walther-Hellwig K. 2001. Untersuchungen zu Sammelflugweiten und Dichteverteilung von Honigbienen. Unveröffentlichte Auftragsarbeit für den Landesverband Hess. Imker e.V., Kirchhain in Zusammenarbeit mit d. Hess. Dienstleistungszentrum f. Landwirtschaft, Gartenbau u, Gartenbau u. Naturschutz (HDLGN), Kirchhain, Germany.

Walther-Hellwig K. and Frankl R. 2000. Foraging habitats and foraging distances of bumblebees, Bombus spp. (Hym., Apidae), in an agricultural landscape. J. Appl. Entomol. 124: 299-306.

Watanabe M.E. 1994. Pollination worries rise as honey bees decline. Science 256: 1170.

Westrich P. 1990. Die Wildbienen Baden-Württembergs. Ulmer, Stuttgart, Germany.

Westrich P., Schwenninger H.R., Dathe H.H., Riemann H., Saure C., Voith J. and Weber K. 1998. Rote Liste der Bienen (Hymenoptera: Apidae). Schriftenreihe für Landschaftspflege und Naturschutz 55: 119-129.

Williams P.H. 1986. Environmental change and the distributions of British bumble bees (Bombus Latr). Bee World 67: 50-61.

Williams P.H. 1989. Why are there so many species of bumble bees at Dungeness. Bot. J. Linn. Soc. 101: 31-44.

Williams I.H., Corbet S.A. and Osborne J.L. 1991. Bee-keeping, wild bees and pollination in the European Community. Bee World 72: 170-180.

Wolf H. 1985. Veränderungen der Hummelfauna (Hymenoptera: Apidae) bei Frankfurt (Main) und Marburg (Lahn). Hessische Faunistische Briefe 5: 66-69. 